\title{
Time series analysis of nutrient inputs to the Baltic Sea and changing DSi:DIN ratios
}

\author{
Lars Rahm ${ }^{1, *}$, Daniel Conley ${ }^{2}$, Per Sandén ${ }^{1}$, Fredrik Wulff ${ }^{3}$, Per Stålnacke ${ }^{1}$ \\ ${ }^{1}$ Dept of Water and Environmental Studies, Linköping University, S-581 83 Linköping, Sweden \\ ${ }^{2}$ National Environmental Research Institute, Fredriksborgvej 399, PO Box 358, DK-4000 Roskilde, Denmark \\ ${ }^{3}$ Dept of Systems Ecology, University of Stockholm, S-106 91 Stockholm, Sweden
}

\begin{abstract}
Increasing nutrient loads have characterized the Baltic Sea during the last century. However, the detection of long-term trends in the water column has been difficult due to both paucity of data and high variability. Analysis of water quality data with robust non-parametric methods has shown statistically significant increases in total nitrogen, total phosphorus, nitrate $\left(\mathrm{NO}_{3}\right)$, and dissolved inorganic phosphate, although with considerable spatial and temporal differences. Significant decreases in dissolved silicate (DSi) and ammonium $\left(\mathrm{NH}_{4}\right)$ concentration have also been reported. We report here significant decreases in the DSi:DIN ratio (where DIN, dissolved inorganic nitrogen, is the sum of $\mathrm{NO}_{3}, \mathrm{NO}_{2}$, and $\mathrm{NH}_{4}$ concentrations) in the Baltic Sea from 1970 to 1990. The molar ratios prior to the formation of the spring bloom are now approaching unity, with further decreases expected with continued eutrophication of the Baltic Sea. This can be explained by an increased net sedimentation of biogenic silica due to increased primary production attributable to increased nutrient loading. While the Baltic proper is generally assumed to be $N$ limited, declining DSi:DIN ratios indicate that spring diatom growth may become DSi limited in the near future, as the optimal DSi:DIN ratio for diatom growth is approximately $1: 1$. This decrease in the DSi:DIN ratio cannot be statistically detected in the river input to the Baltic proper. Only a few significant tests were found in the sea, with both upward and downward trends detected. Ecological implications of this observed reduction in the DSi:DIN ratio may include DSi-limited diatom growth and changes in species composition and subsequently, food web dynamics.
\end{abstract}

KEY WORDS: Dissolved silicate $\cdot$ lnorganic nitrogen $\cdot$ Nutrient ratio $\cdot$ Trend test $\cdot$ Eutrophication $\cdot$ River load B Baltic Sea

\section{INTRODUCTION}

Increased diatom production, due to eutrophication, usually leads to increased sedimentation of diatom silica, e.g, biogenic silica (BSi). Ultimately this results in a decline in the water column pool of dissolved silicate (DSi). Such changes were first reported for the North American Great Lakes (Schelske \& Stoermer 1971, 1972). Similar changes have been reported for the Baltic Sea (Sandén et al. 1991). Recent studies of the sediments in the Mississippi river delta (USA) revealed an increasing deposition of $\mathrm{BSi}$, probably caused by increased riverborne nutrient loads (Turner

\footnotetext{
•E-mail: larra@tema.liu.se
}

\& Rabalais 1994). In fact, these changes seem not to be a regional feature but occur in many freshwater and marine ecosystems throughout the world (Conley et al. 1993)

Schelske \& Stoermer $(1971,1972)$ hypothesized that the limitation of diatom flora through reduced DSi supplies would lead to drastic and undesirable changes in the ecosystem. They argued that the phytoplankton community is likely to be dominated by green algae and cyanobacteria during the summer season if DSi is limiting for diatom growth. This has been discussed in detail in the context of eutrophication in coastal and marine systems by Officer \& Ryther (1980). Egge \& Aksnes (1992) have shown that the availability of DSi can control phytoplankton species composition and biomass. The increases in toxic algal blooms that have 
been observed globally are attributed (Smayda 1989, 1990) to increased loading of nitrogen (N) and phosphorus (P), while the DSi load is unchanged. One such toxic algal bloom has been studied in some detail by Maestrini \& Granéli (1991). They found that the 1988 Chrysochromulina polylepis bloom in the Kattegat on the Swedish west coast was preceded by a spring diatom bloom that exhausted the water masses of DSi and, to some degree, $\mathrm{P}$ but not N. However, no consistent data on frequency and spatial distribution of green algae and cyanobacteria blooms are yet available for the Baltic Sea.

Trend analysis of pelagic nutrient time series have been performed within HELCOM's (Helsinki Commission) assessment work for the Baltic Sea (e.g. Nehring et al. 1990), but with questionable statistical methods (e.g. linear regression). A similar monotonic trend analysis of $\mathrm{P}$ and $\mathrm{N}$ compounds using statistically more robust methods (Sandén \& Rahm 1992) for the period 1970 to 1990 revealed statistically significant increasing concentrations of $N$ and $P$ totals $\left(N_{10 t}\right.$ and $\left.P_{\text {tot }}\right)$ as well as nitrate $\left(\mathrm{NO}_{3}\right)$ and dissolved inorganic phosphate (DIP) at almost all investigated sites in the Baltic Sea. Ammonium $\left(\mathrm{NH}_{4}\right)$ was, however, decreasing in the same areas. This was also true for the DSi concentration, which significantly decreased in the same region from 1968 to 1986 (Sandén et al. 1991). An analysis of trends in DIN:DIP (DIN = dissolved inorganic nitrogen) ratios (L. Rahm, P. Sandén, F. Wulff $\& \AA$. Danielsson unpubl.), over the same period and region, gave only a few significant, decreasing trends in the trophic layer. Decreasing inorganic ratios were found only in the Eastern Gotland Basin while decreasing total ratios were detected in both the Eastern and Western Gotland Basin.

Conley et al. (1993) recognize 2 different types of modification of the nutrient pool. One occurs when the $\mathrm{N}$ and $\mathrm{P}$ load to the system increases but supply of DSi does not. The other is coupled to a reduction of DSi in the water column due to changes in the biogeochemical cycling of $\mathrm{Si}$ as increased diatom production results in increased deposition and retention of BSi in sediments. In basins with long residence times for DSi, even small changes in recycling rates may have large impacts on the pools (Schelske 1975). Wulff \& Stigebrandt (1989) reported residence times of 11, 15 and 18 yr for the Bothnian Bay, Bothnian Sea and Baltic proper, respectively.

To conclude, there are good reasons to investigate the growth conditions for diatoms in the Baltic proper with respect to the ongoing changes in its nutrient status. The increased nutrient load may disrupt the biogeochemical cycles and may lead to changes in diversity and composition of marine organisms. This is investigated in this work by examining DSi:DIN ratios at selected monitoring stations in the Baltic Sea for the period 1970 to 1990 . This trend analysis will be discussed in relation to changes in input load, in nutrient concentrations and in DIN:DIP ratios

Nutrient inputs. The atmospheric load of DIN to the Baltic Sea is estimated by Granat (1990) to have doubled from 1955 to 1990, although the rate of change was weak during the 1980s. The spatial distribution shows a marked northwest-southeast trend with a deposition factor roughly 4 times larger in the south as compared to the north. The annual atmospheric $N_{\text {tot }}$ load to the Baltic Sea based on mean inputs from 1982 to 1987 (Rosenberg et al. 1990) was approximately 25 . 51 and $41 \%$ of the $N_{\text {tot }}$ input for the Bothnian Bay, Bothnian Sea and Baltic proper, respectively. The corresponding estimates for the atmospheric load of DSi are lacking, but assumed to be insignificant with regard to the Baltic Sea.

The riverborne input of nutrients ( $N$ and $P$ ) has recently been estimated by P. Stảlnacke, A. Grimvall, K. Sundblad \& A. Tonderski (unpubl.). It was shown that the total annual average riverborne inputs of $N_{\text {tot }}$ and DIN to the Baltic Sea (input to the Sound, the Belt Sea and the Kattegat not included) are $700 \mathrm{kt}$ and $410 \mathrm{kt}$, respectively, which are higher than previous estimates (Larsson et al. 1985, Rosenberg et al. 1990, HELCOM 1993). Regarding long-term changes in the riverborne load, a small increase of $\mathrm{N}_{\text {tot }}$ can be detected for the 1980s as compared to the 1970 s (Fig. 1A). The increase was, to a large extent, explained by changes in river runoff. Stålnacke et al. (unpubl.) pointed out that the estimate for organic $N\left(N_{\text {org }}\right)$ to the Baltic proper is somewhat uncertain due to the sparse data from the Baltic states and Russia, and could therefore skew the $N_{10 t}$ estimates. In order to get the total land-based input to the Baltic Sea, K. Sundblad (Linköping University, pers. comm.) estimated the direct coastal discharges (i.e. municipalities and industries) to be approximately $80 \mathrm{kt} \mathrm{N}$ annually during the late 1980 s.

According to Larsson et al. (1985) an 8-and 4-fold increase in the supply of $P$ and $N$, respectively, from the land and atmosphere has occurred during this century in the Baltic Sea. The DSi load, on the other hand, should have remained unaltered or perhaps decreased due to construction of reservoirs connected to increased numbers of hydroelectric power stations and the eutrophication of these waters. Grimvall et al. (1991) examined data from 18 rivers in the Baltic Sea region for the period 1972 to 1989 and found remarkably few statistically significant trends in $N$ concentrations, even though the majority of the rivers showed an upward tendency. These findings have been further strengthened in an extended study ( $K$. Sundblad, A. Grimvall \& P. Stålnacke unpubl.). Statistically signifi- 

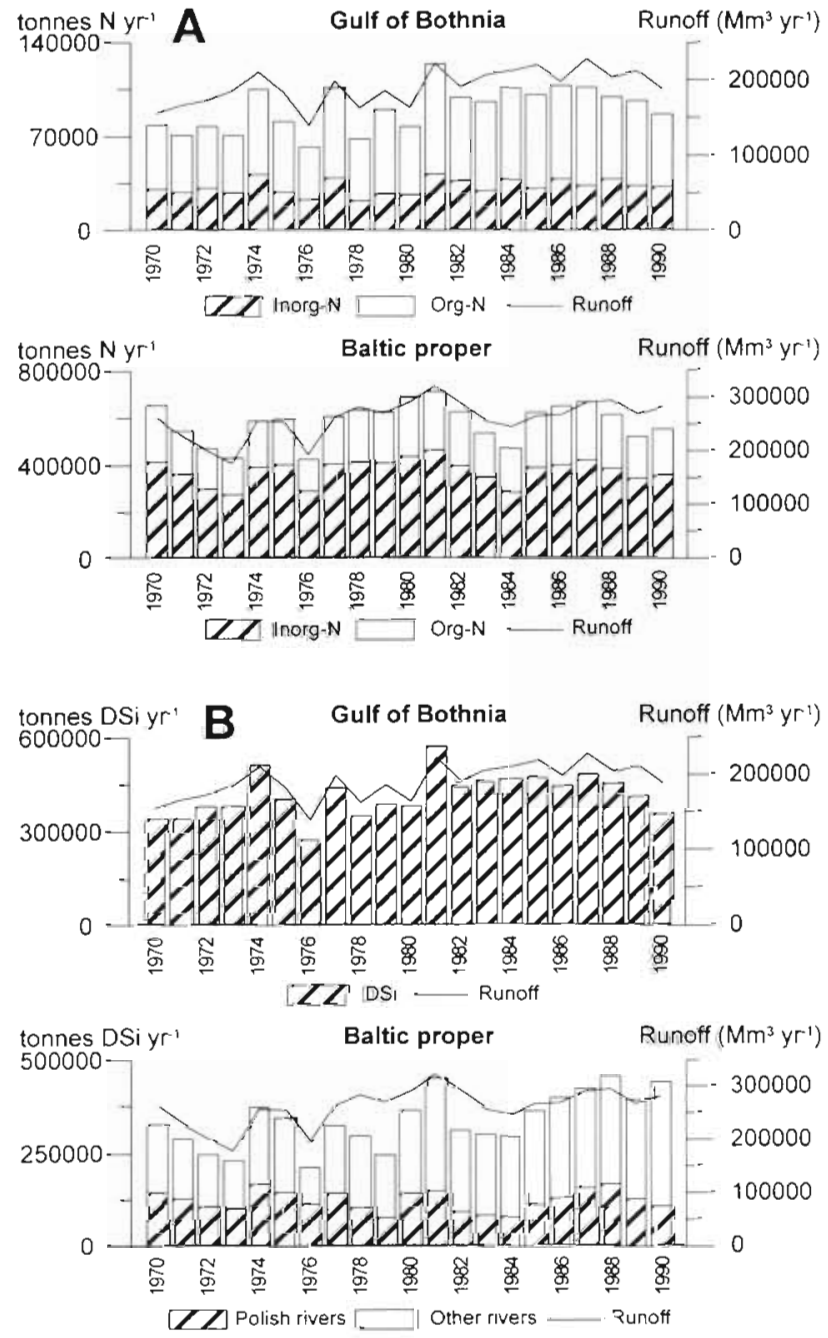

Fig. 1 Annual riverborne export of (A) nitrogen (after Stålnacke et al. unpubl.) and (B) dissolved silicate species with the annual river runoff to the Gulf of Bothnia and to the Baltic proper

cant upward trends for $\mathrm{NO}_{3}$ concentrations have been found in some rivers of the Baltic states (e.g. in Latvia; Tsirkunov et al. 1992). A slight downward tendency in concentration (not statistically significant) has, however, been observed recently and is probably related to the dramatic drop in commercial fertilizer use in the Baltic states from 1987 onward.

The DSi and $\mathrm{N}_{\text {tot }}$ inputs from the land and atmosphere have been estimated for the period 1971 to 1981 by Wulff \& Stigebrandt (1989) to be 129,150 and $523 \mathrm{kt}$ DSi $\mathrm{yr}^{-1}$ and 29, 128 and $850 \mathrm{kt} \mathrm{N}_{\text {tot } \mathrm{Yr}^{-1}}$ for Bothnian Bay, Bothnian Sea and the Baltic proper, respectively. This gives DSi: $\mathrm{N}_{\text {tot }}$ ratios (by atoms) of roughly $2.2,0.6$ and 0.3 for the load to the respective basins when the advective fluxes between them have been adjusted for (Wulff \& Stigebrandt 1989). The estimated input of $\mathrm{N}_{\text {tot }}$ includes, however, all $N$ compounds, irrespective of their labile or refractory character. Hence one must consider this as a lower limit for the ratio. The corresponding ratios based on the pools in the sub-basins become $1.3,1.1$ and 1.2 when based on the above premises. The higher ratios for the pelagic pools reflect the more effective $\mathrm{N}$ sinks compared to $\mathrm{Si}$.

\section{METHODS AND MATERIALS}

The land-based input of DSi to the Baltic Sea is estimated by combining time series of river water quality data, gathered from approximately 100 sampling sites and mainly obtained from national monitoring programmes, with time series of river runoff data (Bergström \& Carlsson 1994). Linear interpolation in the water quality series is used to fill in minor gaps while major gaps are filled in by estimating seasonal components and extrapolating trends from nearby rivers with a non-parametric test suggested by McLeod et al. (1983). The contribution from non-monitored coastal drainage basins is estimated by combining calculated runoff with observed concentrations from adjacent rivers. The DSi supply from the large Polish rivers (i.e. Vistula and Oder) is estimated with the combined data from the Neman (Lithuanian) and Daugava (Latvian) rivers. The methods and procedures for the DSi data follow to a large extent those presented for $\mathrm{N}$ and $\mathrm{P}$ by Stålnacke et al. (unpubl.). The contribution from direct coastal point sources of DSi is regarded as insignificant.

Time series of DSi and nutrient ratios were analyzed for trends in both river waters and the sea. Regarding the river data, the number of sampling sites was restricted to 10 for rivers discharging into the Baltic proper and to 12 for the Gulf of Bothnia (see Table 2). The time period studied varied among sampling sites, but most data were from 1970 to 1990 .

The analyses of the time series of nutrient ratios are based on simultaneous observations of DSi and the DIN species, i.e. $\mathrm{NO}_{3}, \mathrm{NH}_{4}$ and nitrite $\left(\mathrm{NO}_{2}\right)$, over the period 1970 to 1990 . The data originate from the HELCOM databank in Helsinki and the ICES (International Council for the Exploration of the Sea) databank in Copenhagen. Standard sampling and analytical methods were used in the chemical analysis (HELCOM 1984). These techniques did not change during the test period. There is, unfortunately, a marked lack of data from the northern part of the Gulf of Bothnia, especially for the ice-covered seasons, which will influence the analysis. The study is restricted to the trophic layer of the entire Baltic Sea, i.e. 0 to $30 \mathrm{~m}$. Four different seasons were studied (January to March, April to June, July to September 
and October to December). If more than 1 sample exists for a given depth interval and season, the median value was used. Nine stations with relatively high observation frequency, representing the 3 major sub-basins, were chosen for analysis.

The trend test used was a modified Mann-Kendall test (Mann 1945, Kendall 1975). This is a nonparametric test for monotonic trends and was adapted for seasonal data by Hirsch et al. (1982). Hirsch \& Slack (1984) modified the test to account for covariation between seasons. In essence, the test can be described as the sum of the number of positive differences between an observation and all later observations minus the sum of all negative differences. This value is then divided by the square root of the variance to form the standard normal variate.

More formally, the test statistic $S$ is calculated independently over $n$ years for each season $g$ according to

$$
S_{g}=\sum_{i=1}^{n_{g}-1} \sum_{j=1+1}^{n_{g}} \operatorname{sgn}\left(x_{j g}-x_{i g}\right)
$$

where $x$ is observed values, $n_{g}$ is the number of nonmissing observations in season $g$ and

$$
\operatorname{sgn}(\theta)=\left\{\begin{array}{r}
1 \text { if } \theta>0 \\
0 \text { if } \theta=0 \\
-1 \text { if } \theta<0
\end{array}\right\}
$$

The overall test is then calculated as

$$
S=\sum_{g=1}^{p} S_{g}
$$

where $p$ is the number of seasons, which is asymptotically normal with 0 mean and variance according to

$$
\operatorname{var}(S)=\sum_{g=1}^{p} \sigma_{g}^{2}+\sum_{\substack{g, h \\ g \neq h}} \sigma_{g h}
$$

where $\sigma_{g}^{2}=\operatorname{var}\left(S_{g}\right)$ and $\sigma_{g h}=\operatorname{cov}\left(S_{g}, S_{h}\right)$. The variance is given by the equation

$$
\sigma_{g}^{2}=\left(n_{g}\left(n_{g}-1\right)\left(2 n_{g}+5\right)-\sum_{i=1}^{m} t_{j}\left(t_{j}-1\right)\left(2 t_{j}+5\right)\right) / 18
$$

where $m$ is the number of tied groups and $t$, is the size of the $j$ th tied group. The covariance $\sigma_{g h}$ is estimated by $\hat{\sigma}_{g h}$ according to

$$
\hat{\sigma}_{g h}=\left(K_{g h}+4 \sum_{i=1}^{n} R_{i g} R_{h h}-n\left(n_{g}+1\right)\left(n_{h}+1\right)\right) / 3
$$

where $n$ is the number of years, $n_{g}$ and $n_{\mathrm{h}}$ are the number of observations for seasons $g$ and $h$ respectively and

$$
K_{g h}=\sum_{i=1}^{n-1} \sum_{j=i+1}^{n} \operatorname{sgn}\left[\left(x_{j g}-x_{l g}\right)\left(x_{j h}-x_{1 h}\right)\right]
$$

$$
R_{1 g}=\left(n_{g}+1+\sum_{j=1}^{n} \operatorname{sgn}\left(x_{i g}-x_{j g}\right)\right) / 2
$$

The standard normal variate is then calculated as

$$
Z=\left\{\begin{array}{cl}
\frac{S-1}{\sqrt{\operatorname{var}(S)}} & \text { if } S>0 \\
0 & \text { if } S=0 \\
\frac{S+1}{\sqrt{\operatorname{var}(S)}} & \text { if } S<0
\end{array}\right.
$$

This test is robust against non-normal distribution, extreme values, serial correlation and seasonality, and it can handle missing and censored data.

To get an estimate of the trend slope we used the seasonal Kendall slope estimator proposed by Hirsch et al. (1982). This can be characterized as the median annual change adjusted for seasonality. More precisely, the slope $B$ is the median of all $d_{g_{j}}$, where

$$
d_{g j}=\frac{x_{g i}-x_{g j}}{i-j} \quad 1 \leq j<i \leq n
$$

This estimator is resistant to extreme values and unaffected by seasonality in contrast to a linear regression estimator of the slope. All tests were carried out as 2 -sided tests since both upward and downward trends were of interest.

\section{RESULTS AND DISCUSSION}

Brzezinski (1985) reported compositional Si:N ratios of marine planktonic diatoms in the range $1.12 \pm 0.33$ for 27 different species and it is reasonable to assume similar ratios for the species found in the Baltic Sea The limiting DSi:DIN ratio for diatom growth depends on several factors such as the rate of Si recycling in comparison to other major nutrients and the ability of diatoms to vary wall thickness and thus cellular Si content with DSi supply (Paasche 1980). The recycling of $\mathrm{N}$ and $\mathrm{P}$ is assumed to be rapid relative to that of BSi (Officer \& Ryther 1980), and the dissolution of diatom frustules in sediments is a slow process compared to the regeneration of other nutrients (Conley \& Johnstone 1995). These considerations would allow for a practical limiting ratio well above the compositional ratios reported above, whereas adjustments of diatom Si content would give the opposite result. We suggest a limiting range of DSi:DIN of $\sim 0.5$ to 1.5 by atom as an operational definition.

The actual concentration of DSi will also be important in determining whether diatom production is limited by DSi or other nutrients. Goering et al. (1973) and Azam \& Chisholm (1976) reported from tracer experiments that DSi uptake was markedly limited at 
ambient DSi concentrations of about 1.6 to $3.6 \mu \mathrm{M}$. Egge \& Aksnes (1992) also reported DSi limitation of diatom production for concentrations below $2 \mu \mathrm{M}$. Hence it seems fair to assume a restriction in growth for concentrations in the range of 1 to $4 \mu \mathrm{M}$. The monotonic DSi trend estimates by Sandén et al. (1991), for almost the same stations in the Baltic Sea as were used here, give, as end values for the study period, DSi concentrations in the range discussed above for some stations in the Baltic proper. Water column DSi:DIN ratios for each sub-basin during March (Wulff et al. 1994a), for 5 yr periods over 2 decades, also give decreasing ratios (Table 1 ). These findings are indica-

Table 1 DSi: $\mathrm{N}_{\text {tol }}$ ratios by atoms based on $5 \mathrm{yr}$ means of the water mass in the major basins of the Baltic Sea in March (Wulff et al. 1994). The ratio, based on total load to respective basin (Wulff \& Stigebrandt 1989) and adjusted for interbasin exchange, is shown at the bottom. --: missing data

\begin{tabular}{|lccc|}
\hline & Bothnian Bay & Bothnian Sea & Baltic proper \\
\hline $1972-1976$ & - & - & 6.3 \\
$1977-1981$ & 4.9 & 5.7 & 5.1 \\
$1982-1986$ & 3.9 & 4.2 & 4.4 \\
$1987-1991$ & 2.3 & 3.2 & 2.8 \\
DSi: $N_{101}$ & 2.2 & 0.6 & 0.3 \\
\hline
\end{tabular}

tors of ongoing large-scale changes in the ecosystem. However, since the uncertainty in these estimates of total amounts is unknown, the actual significance level of this trend cannot be given.

\section{Trends in river load}

It was estimated that the Baltic Sea received on average approximately $750 \mathrm{kt}$ DSi annually from 1970 to 1990 from surrounding rivers (Fig. 1B). The DSi concentrations in the observed time series were quite stable during the entire period, and the annual fluctuations can largely be explained by changes in runoff (Fig. 1B). The rather sparse data from the Baltic states and Russia and the total lack of data for the large Polish rivers, Vistula and Oder, contribute to the uncertainty in the load estimates and make it difficult to draw conclusions about the true DSi suppply from rivers to the Baltic Sea. However, the estimates are likely to be in the right order of magnitude.

The trend analysis of DSi concentrations and nutrient ratios in the investigated rivers (Table 2) showed only a few statistically significant trends. In the 10 rivers discharging into the Baltic proper, 1 positive trend and 1 negative trend were detected for the ratios of DSi:DIN (significance level $\alpha=0.05$ ). For DSi, 3 pos-

Table 2. Monotonic trend analysis on dissolved silicate and ratios of DSi:inorganic $\mathrm{N}$ in river waters discharging into the Gulf of Bothnia and the Baltic proper. Only rivers with a runoff above $50 \mathrm{~m}^{3} \mathrm{~s}^{-1}$ are presented. Statistical method was based on Hirsch \& Slack (1984) with flow adjustment and no assumption of independence

\begin{tabular}{|c|c|c|c|c|c|c|c|c|c|c|}
\hline \multirow{2}{*}{ River } & \multirow{2}{*}{$\begin{array}{l}\text { Mean } \\
\text { runoff } \\
\left(\mathrm{m}^{3} \mathrm{~s}^{-1}\right)\end{array}$} & \multicolumn{5}{|c|}{$\longrightarrow$ Dissolved silicate } & \multicolumn{4}{|c|}{ DSi:inorganic $N$} \\
\hline & & Period & $\mathrm{n}$ & $\begin{array}{c}\text { Mean conc } \\
\left(\mu \mathrm{mol} \mathrm{I}^{-1}\right)\end{array}$ & $\begin{array}{l}\text { Test } \\
\text { var }\end{array}$ & $\mathrm{p}$ & Period & $\mathrm{n}$ & $\begin{array}{l}\text { Test } \\
\text { var. }\end{array}$ & $\mathrm{p}$ \\
\hline \multicolumn{11}{|l|}{ Baltic proper } \\
\hline Motala ström & 85.9 & $70-90$ & 249 & 29 & -3.012 & 0.0026 & $70-90$ & 249 & -1.943 & 0.0520 \\
\hline Norrström (Stockholm) & 158.5 & $70-90$ & 242 & 18 & -0.049 & 0.9609 & $70-90$ & 242 & 1.782 & 0.0747 \\
\hline Kymijoki & 307.7 & $71-90$ & 178 & 35 & 0.906 & 0.3649 & $74-86$ & 116 & -2.059 & 0.0395 \\
\hline Neva & 2592.0 & $81-88$ & 46 & 10 & 1.390 & 0.1645 & $81-89$ & 46 & 1.487 & 0.1370 \\
\hline Narva & 452.0 & $80-89$ & 64 & 45 & 0.608 & 0.5432 & $80-89$ & 64 & 0.830 & 0.4065 \\
\hline Pärnu & 57.7 & $80-89$ & 40 & 60 & 1.536 & 0.1245 & $80-89$ & 38 & 1.741 & 0.0817 \\
\hline Gauja & 70.7 & $77-90$ & 132 & 76 & 2.365 & 0.0180 & $77-90$ & 132 & 0.682 & 0.4952 \\
\hline Daugava & 697.8 & $77-90$ & 168 & 57 & 1.348 & 0.1777 & $77-90$ & 168 & -1.558 & 0.1192 \\
\hline Lielupe & 139.8 & $77-90$ & 169 & 73 & 1.202 & 0.2294 & $77-90$ & 169 & 0.983 & 0.3256 \\
\hline Neman & 558.6 & $77-87$ & 79 & 64 & 3.531 & 0.0004 & $77-90$ & 79 & 2.338 & 0.0194 \\
\hline \multicolumn{11}{|l|}{ Gulf of Bothnia } \\
\hline Dalälven & 338.7 & $70-90$ & 227 & 69 & 1.138 & 0.2551 & $70-90$ & 227 & -1.239 & 0.2153 \\
\hline Ljusnan & 222.2 & $70-90$ & 216 & 87 & -0.372 & 0.7099 & $70-90$ & 216 & 2.778 & 0.0055 \\
\hline Indalsälven & 444.9 & $70-90$ & 229 & 32 & 1.559 & 0.1190 & $70-90$ & 229 & -2.790 & 0.0053 \\
\hline Ångermanälven & 493.0 & $70-90$ & 243 & 48 & 0.390 & 0.6965 & $70-90$ & 243 & -0.060 & 0.9522 \\
\hline Ume älv & 444.3 & $70-90$ & 246 & 48 & 0.469 & 0.6391 & $70-90$ & 246 & 0.717 & 0.4734 \\
\hline Lule älv & 489.8 & $70-90$ & 248 & 41 & 1.990 & 0.0466 & $70-90$ & 248 & 2.632 & 0.0085 \\
\hline Kalix älv & 287.9 & $70-90$ & 242 & 97 & 0.138 & 0.89024 & $70-90$ & 242 & -2.223 & 0.0262 \\
\hline Torne älv & 382.1 & $70-90$ & 247 & 112 & -0.289 & 0.77258 & $70-90$ & 247 & -0.930 & 0.3524 \\
\hline Kemijoki & 539.3 & $71-90$ & 129 & 117 & -2.213 & 0.0269 & $75-87$ & 86 & -0.141 & 0.8879 \\
\hline lijoki & 167.4 & $70-90$ & 130 & 109 & -2.321 & 0.02029 & $75-88$ & 106 & -1.615 & 0.1063 \\
\hline Oulujoki & 258.3 & $70-90$ & 187 & 45 & -0.136 & 0.8918 & $73-87$ & 136 & 2.840 & 0.0045 \\
\hline Kokenmäenjoki & 237.9 & $74-90$ & 157 & 66 & -0.818 & 0.41336 & $74-90$ & 134 & 0.078 & 0.9378 \\
\hline
\end{tabular}




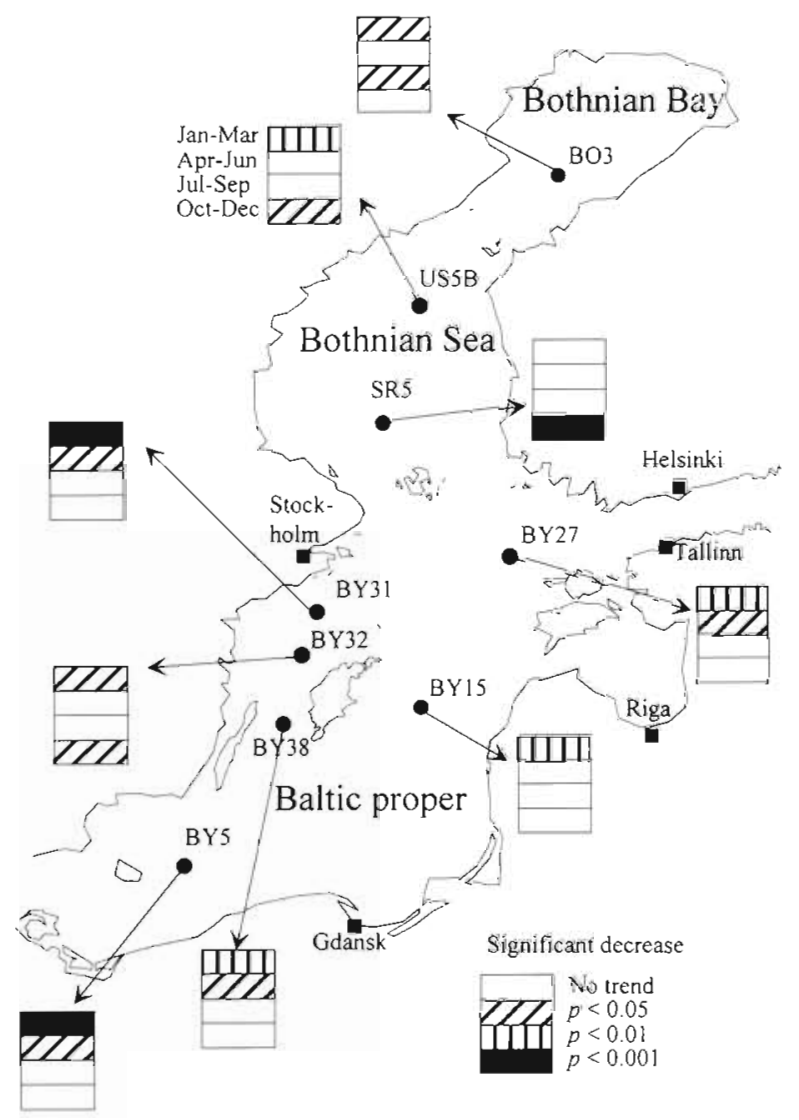

Fig. 2. Significant trends of DSi:DIN ratios for the 4 seasons at 9 stations in the Baltic Sea

itive trends ( 3 out of 10 , i.e. $30 \%$ ) were found. Of the rivers discharging into the Gulf of Bothnia, 1 significant upward DSi trend was detected (Lule älv River, Sweden) and only 2 of the rivers, Kemijoki and Iijoki in Finland, were found to have negative downward DSi trends.

\section{Trends in the water mass}

The results of the trend analysis in the Baltic Sea are shown in Table 3 and Fig. 2. Significantly decreasing trends $(p<0.05)$ for the DSi:DIN ratio on an annual basis were found at all stations investigated (of the order 5 to $10 \% \mathrm{yr}^{-1}$ ) even when serial independence was not assumed. This corroborated previous trend tests of the Baltic Sea (Sandén et al. 1991, Sandén \& Rahm 1992) with regard to the inverse response of DSi to $\mathrm{NO}_{3}$ concentrations in the water mass.

The few observed downward trends in the DSi:N ratio of the river load support the hypothesis that the decrease in DSi:DIN ratio in the sea cannot be explained by a corresponding decrease in river input. Finally, there are few indications of changes in the
Table 3. Monotonic trend test on simultaneous observations of DSi:inorganic $N$ at depth interval 0 to $30 \mathrm{~m}$ at different sampling stations in the Baltic Sea. Number of observations, $S$ statistics, median ratio and estimated slope $\left(\mathrm{yr}^{-1}\right)$ are presented. (See Fig. 2 for station locations)

\begin{tabular}{|c|c|c|c|c|c|c|}
\hline Station & Season & $\mathrm{n}$ & Median & Test var. & $\mathrm{p}$ & Slope \\
\hline \multirow[t]{5}{*}{$\mathrm{BO} 3$} & Winter & 6 & 3.81 & -2.254 & 0.0242 & -0.129 \\
\hline & Spring & 10 & 4.44 & 0.894 & 0.3711 & 0.036 \\
\hline & Summer & 15 & 8.75 & -2.177 & 0.0294 & -0.495 \\
\hline & Autumn & 7 & 4.63 & -0.601 & 0.5480 & -0.047 \\
\hline & Total & 38 & & -2.465 & 0.0137 & -0.083 \\
\hline \multirow[t]{5}{*}{ US5B } & Winter & 10 & 0.23 & 3.041 & 0.0024 & 0.011 \\
\hline & Spring & 8 & 0.05 & 0.000 & 1.0000 & -0.000 \\
\hline & Summer & 11 & 0.02 & 1.401 & 0.1611 & 0.002 \\
\hline & Autumn & 12 & 0.14 & 2.263 & 0.0236 & 0.005 \\
\hline & Total & 41 & & 2.779 & 0.0055 & 0.005 \\
\hline \multirow[t]{5}{*}{ SR5 } & Winter & 5 & 4.67 & -1.715 & 0.0864 & -0.272 \\
\hline & Spring & 10 & 18.69 & -0.716 & 0.4743 & -0.722 \\
\hline & Summer & 9 & 20.71 & -1.564 & 0.1179 & -1.028 \\
\hline & Autumn & 16 & 8.11 & -2.927 & 0.0034 & -0.441 \\
\hline & Total & 40 & & -3.332 & 0.0009 & -0.472 \\
\hline \multirow[t]{5}{*}{ BY27 } & Winter & 13 & 4,65 & -3.234 & 0.0012 & -0.291 \\
\hline & Spring & 9 & 12.86 & -2.189 & 0.0286 & -1.835 \\
\hline & Summer & 7 & 23.96 & -1.202 & 0.2296 & -1.234 \\
\hline & Autumn & 15 & 3.63 & -1.485 & 0.1376 & -0.073 \\
\hline & Total & 44 & & -3.424 & 0.0006 & -0.215 \\
\hline \multirow[t]{5}{*}{ BY31 } & Winter & 17 & 4.36 & -3.584 & 0.0003 & -0.319 \\
\hline & Spring & 14 & 18.87 & -2.518 & 0.0118 & -1.629 \\
\hline & Summer & 12 & 24.63 & -0.754 & 0.4507 & -0.950 \\
\hline & Autumn & 18 & 6.68 & -0.606 & 0.5445 & -0.099 \\
\hline & Total & 61 & & -2.759 & 0.0058 & -0.382 \\
\hline \multirow[t]{5}{*}{ BY32 } & Winter & 7 & 4.38 & -2.103 & 0.0355 & -0.362 \\
\hline & Spring & 6 & 18.18 & -0.752 & 0.4524 & -0.608 \\
\hline & Summer & 8 & 21.33 & 1.361 & 0.1735 & 0.691 \\
\hline & Autumn & 9 & 6.96 & 1.981 & 0.0476 & 0.195 \\
\hline & Total & 30 & & 1.065 & 0.2868 & 0.072 \\
\hline \multirow[t]{5}{*}{ BY38 } & Winter & 18 & 4.64 & -3.258 & 0.0011 & -0.277 \\
\hline & Spring & 16 & 12.11 & -2.206 & 0.0274 & -1.416 \\
\hline & Summer & 16 & 12.41 & -0.855 & 0.3923 & -0.376 \\
\hline & Autumn & 17 & 8.03 & -1.524 & 0.1275 & -0.259 \\
\hline & Total & 67 & & -2.770 & 0.0056 & -0.384 \\
\hline \multirow[t]{5}{*}{ BY15 } & Winter & 20 & 3.64 & -3.082 & 0.0021 & -0.147 \\
\hline & Spring & 16 & 6.30 & 0.045 & 0.9641 & 0.014 \\
\hline & Summer & 22 & 17.35 & -1.072 & 0.2839 & -0.311 \\
\hline & Autumn & 22 & 5.72 & -0.056 & 0.9550 & -0.029 \\
\hline & Total & 80 & & -1.811 & 0.0701 & -0.111 \\
\hline \multirow[t]{5}{*}{ BY5 } & Winter & 21 & 5.12 & -3.714 & 0.0003 & -0.238 \\
\hline & Spring & 18 & 13.71 & -2.424 & 0.0153 & -0.906 \\
\hline & Summer & 17 & 12.26 & -0.783 & 0.1082 & -0.553 \\
\hline & Autumn & 20 & 6.36 & -0.552 & 0.5376 & -0.050 \\
\hline & Total & 76 & & -2.720 & 0.0045 & -0.227 \\
\hline
\end{tabular}

riverine loads of $\mathrm{N}$ and DSi to the respective basins, except those coupled to interannual variations in freshwater runoff (Fig 1). The long-term increase in atmospheric $N$ deposition (Granat 1990) may alter the DSi:N ratio of the load, but recent investigations indicate that the increase in atmospheric $\mathrm{N}$ deposition leveled off 
during the 1980s (L. Granat, Stockholm University, pers. comm.).

Significant decreases in the DSi:DIN ratio over the test period were primarily observed during winter. The pre-spring bloom is the most crucial time period in any investigation of DSi limitation of primary production. These results corroborate the more coarse, but robust, estimates by Wulff et al. (1994b) based on 5 yr means of total amounts for the Baltic Sea subbasins. Extrapolation of the present ratios using the estimated monotonic slope to the end of the investigation period yields ratios for the top $30 \mathrm{~m}$ within or near the production limits suggested by the Redfield ratio. Hence it seems reasonable to assume that the spring bloom may soon become DSi limited. Regional differences in trends are also discernible, with lower trends observed in the northern Baltic Sea, and may be related to differences in recycling rate (Conley et al. 1993). In addition, the spring bloom occurs later and is smaller in the phosphorus-limited oligotrophic subarctic Bothnian Bay than in the other basins (Wulff et al. 1994a).

The relative ratio between DSi and DIN is, however, of minor importance as soon as biological activities begin after the winter season. Because the recycling rates for the 2 fractions differ substantially, with $\mathrm{N}$ recycling rates rapid in comparison with those of $\mathrm{Si}, \mathrm{N}$ limitation of production is more probable than DSi limitation of production. More important for the limitation of the primary production is the concentration of DSi after the start of the spring bloom. Extrapolation of the monotonic trends in Sandén et al. (1991), based on average concentration and the estimated trend, to 1991 for the spring season (April to June) suggests very low concentrations in the photic zone. Nature is, however, rarely linear in its behaviour. We can only suggest that it is probable that the Baltic ecosystem is approaching a DSi-limited state for the diatom portion of the spring bloom. Multiannual studies of species composition are needed to verify our hypothesis. There are some recent observations from the southern part of the Baltic proper that corroborate our expectations. For example, Munk-Sörensen \& Nielsen (1992) reported DSi:DIN <2 and DSi concentrations $<1 \mu \mathrm{M}$ after the spring bloom.

The large-scale effects of a DSi-limited spring bloom are unclear, although both Schelske \& Stoermer (1972) and Officer \& Ryther (1980) have pointed out the risk of drastic and undesired changes to the whole ecosystem. The remedy is obviously a coordinated decrease in both $\mathrm{N}$ and $\mathrm{P}$ load. A decrease in only the $\mathrm{N}$ load may favour only cyanobacterial $\mathrm{N}$ fixation and green algal blooms. On the other hand, the economic realities of the countries around the Baltic Sea probably exclude a major remedy action (Wulff \& Niemi 1992). Clever use of the 'bottlenecks' of the system is probably a more convenient way to lessen the load on this system. It is in this perspective that one should look at the present work, which identifies an ongoing change towards a DSi-limited spring bloom in the ecosystem. Hypothetically, a shift away from a diatom-dominated system may have far-reaching consequences on nutrient recycling processes (Conley et al. 1993). The system would probably go from one characterized by the efficient biologically mediated deposition of organic matter with efficient nutrient sink to a highly recycled system and inefficient nutrient sinks with the sediments playing a reduced role in nutrient recycling processes. While diatom blooms are mainly deposited, cyanobacteria often come to surface in the terminal phase of their blooms, whereafter they are primarily degraded in the trophic layer with the released nutrients to be easily taken up by biota again.

Acknowledgements. This work was supported by the Swedish Environmental Protection Agency (SNV), the Swedish Natural Science Council (NFR) and the U.S. National Science Foundation (International Programs). Thanks also to the institutes in Sweden, Finland, Russia, Estonia, Latvia, Lithuania, Poland and Germany for providing us with water quality data. We thank 3 anonymous referees for constructive comments. We also thank Dr M. Rodriguez-Medina and Ms $\AA$. Danielsson for valuable advice

\section{LITERATURE CITED}

Azam F, Chisholm SW (1976) Silicic acid uptake and incorporation by natural marine phytoplankton populations Limnol Oceanogr 21:427-435

Bergström S, Carlsson B (1994) River runoff to the Baltic Sea: 1950-1990. Ambio 23:280-287

Brzezinski MA (1985) The Si:C:N ratio of marine diatoms: interspecific variability and the effect of some environmental variables. J Phycol 21:347-357

Conley DJ, Johnstone R (1995) Biogeochemistry of N, P and Si in Baltic Sea sediments: response to a simulated deposition of the spring diatom bloom. Mar Ecol Prog Ser 122:265-276

Conley DJ, Schelske CL. Stoermer EF (1993) Modification of the biogeochemical cycle of silica with eutrophication Mar Ecol Prog Ser 101:179-192

Egge JK, Aksnes DL (1992) Silicate as regulating nutrient in phytoplankton competition. Mar Ecol Prog Ser 83:281-289

Goering JJ, Nelson DM, Carter JA (1973) Silicic acid uptake by natural populations of marine phytoplankton. Deep Sea Res 20:777-789

Granat L (1990) Estimating atmospheric nitrogen loading to the Baltic Sea. Ambio Spec Rep 7:20-21

Grimvall A, Stålnacke P, Sundblad K, Niemirycz E, Pitkänen H. Bruhn A (1991) Trend analysis of nutrient concentrations in Baltic Sea rivers. In: Fenger J, Halsnæes K, Larsen H, Schroll H, Vidal V (eds) Environment, Energy and Natural Resource Management in the Baltic Region, Copenhagen, Denmark, May 7-10, 1991. Nord 1991; 48, p $333-344$

HELCOM (1984) Guidelines for the Baltic Monitoring Programme for the second stage. Helsinki Commission, Helsinki, Baltic Sea Environmental Proceedings 12:1-249 
HELCOM (1993) Second pollution load compilation, PLC-2 Baltic Marine Environment Protection Commission. Helsinki Commission, March 1993

Hirsch RM. Slack JR (1984) A nonparametric trend test for seasonal data with serial dependence. Water Resour Res 20:727-732

Hirsch RM, Slack JR, Smith RA (1982) Techniques of trend analysis for monthly water quality data. Water Resour Res 18:107-121

Kendall MG (1975) Rank correlation methods. Charles Griffin, London

Larsson U, Elmgren R, Wulff F (1985) Eutrophication and the Baltic Sea. Ambio 14:9-14

Maestrini SY, Granéli E (1991) Environmental conditions and ecophysiological mechanisms which led to the 1988 Chrysochromulina polylepis bloom: an hypothesis Oceanol Acta 14:397-413

Mann HB (1945) Non-parametric test against trend. Econometrics 13:245-259

McLeod AI, Hipel KW, Comancho F (1983) Trend assessment of water quality time series. Water Resour Bull 19:537-546

Munk-Sörensen H, Nielsen K (1992) Åhus bugt 1990-1991; Hydrografi, närsalter og plankton. Ahus Amt, \&hus

Nehring D, Hansen HP, Jörgensen LA, Körner D, Mazmachs M, Perttilä M, Trzosinska A, Wulff $F$, Yurkovskis A (1990) Nutrients. In: Nehring D, Hansen HP (eds) Second periodic assessment of the state of the marine environment of the Baltic Sea area, 1984-1988. Background document Baltic Sea Environ Proc 35B:110-152

Officer CB, Ryther JH (1980) The possible importance of silicon in marine eutrophication. Mar Ecol Prog Ser 3:83-91

Paasche E (1980) Silicon. In: Morris I (ed) The physiological ecology of phytoplankton. Blackwell, Oxford p 259-284

Rosenberg R, Elmgren R, Fleischer S, Jonsson P, Persson G, Dahlin H (1990) Marine eutrophication case studies in Sweden. Ambio 19:102-108

Sandén P, Rahm L (1992) Nutrient trends in the Baltic Sea Environmetrics 4:75-103

This article was submitted to the editor
Sandén P, Rahm L, Wulff F (1991) Non-parametric trend test of Baltic Sea data. Environmetrics 2:263-278

Schelske CL (1975) Silica and nitrate depletion as related to rate of eutrophication in Lakes Michıgan, Huron and Superior In: Hasler AD (ed) Coupling of land and water systems. Springer Verlag, New York, p 277-298

Schelske CL, Stoermer EF (1971) Eutrophication, silica depletion and prediced changes in algal quality in Lake Michigan. Can J Fish Aquat Sci 48:1529-1538

Schelske CL, Stoermer EF (1972) Phosphorus, silica and eutrophication in Lake Michigan. In: Likens GE (ed) Nutrients and eutrophication. Special Symposia, American Soclety for Limnology and Oceanography, Lawrence, KS, Vol 1, p 157-171

Smayda TJ (1989) Primary production and the global epidemic of phytoplankton blooms in the sea: a linkage? In: Cosper EM, Bricelj VM, Carpenter EJ (eds) Novel phytoplankton blooms. Springer, New York, p 449-483

Smayda TJ (1990) Novel and nuisance phytoplankton blooms in the sea: evidence for a global epidemic. In: Granéli E (ed) Toxic marine phytoplankton. Elsevier, London, p 29-40

Tsirkunov VV, Nikanorov AM, Laznik MM, Dongwei Z (1992) Analysis of long-term and seasonal river water quality changes in Latvia. Wat Res 26:1203-1216

Turner, RE, Rabalais NN (1994) Coastal eutrophication near the Mississippi river delta. Nature 368:619-621

Wulff F, Niemi $\AA$ (1992) Priorities for the restoration of the Baltic Sea - a scientific perspective. Ambio 21:193-195

Wulff F, Pertillä M, Rahm L (1994b) Mass-balance calculations of nutrients and hydrochemical conditions in the Gulf of Bothnia, 1991. Aqua Fennica 24:121-140

Wulff F, Rahm L, Rodriguez-Medina M (1994a) Long-term and regional variations of nutrients in the Baltic Sea; 1971-1991. Finn mar Res 26:35-50

Wulff F, Stigebrandt A (1989) A time-dependent budget model for nutrients in the Baltic Sea. Global biogeochem Cycles 3:53-78

Manuscript first received: January 1, 1995

Revised version accepted: August 11, 1995 